\title{
STUDI KLASIFIKASI BERBASIS OBJEK UNTUK KESESUAIAN TUTUPAN LAHAN TAMBAK, KONSERVASI DAN PERMUKIMAN KAWASAN PESISIR \\ (STUDI KASUS: KEC.ASEMROWO, KREMBANGAN, PABEAN CANTIKAN, DAN SEMAMPIR, KOTA SURABAYA)
}

\author{
Indra Jaya Kusuma, Hepi Hapsari Handayani \\ Program Studi Teknik Geomatika, FTSP, ITS-Sukolilo, Surabaya, 60111 \\ Email : hapsari@geodesy.its.ac.id
}

\begin{abstract}
Abstrak
Pemanfaatan lahan di kawasan pesisir menjadi salah satu penyebab utama terjadinya permasalahan pada kawasan pesisir yang mempengaruhi penyimpangan tata guna lahan di suatu kawasan. Untuk mengurangi penyimpangan tata guna lahan dibutuhkan analisis mengenai kesesuaian tutupan lahan dengan menggunakan teknologi penginderaan jauh dan dengan dukungan analisis Sistem Informasi Geografis (SIG) yang digunakan fungsi overlay dan buffering.

Lokasi penelitian ini terdiri dari empat kecamatan yaitu Kecamatan Asemrowo, Kecamatan Krembangan, Kecamatan Pabean Cantikan, dan Kecamatan Semampir dimana wilayah tersebut akan dianalisis kesesuaian tutupan lahan berdasarkan lahan tambak, konservasi, dan permukiman. Pada penelitian ini menentukan tutupan lahan berdasarkan kategori sesuai (S1), Sesuai bersyarat (S2), dan tidak sesuai (N1).

Data citra yang digunakan untuk menentukan tutupan lahan pada penelitian ini adalah citra Worldview-2 tahun 2013, dan metode klasifikasi yang digunakan pada proses pengolahan citra ini adalah klasifikasi berbasis objek. Pada analisa kesesuaian tutupan lahan dilakukan proses analisa kesesuaian dengan menggunakan fungsi analisis Sistem Informasi Geografis menggunakan metode overlay dan buffering. Berdasarkan hasil tutupan lahan yang didapatkan dengan menggunakan klasifikasi berbasisis objek didapatkan 7 kelas yaitu Permukiman 617,453 Ha, Industri dan pergudangan 544,962 Ha, RTH 401,066 Ha, Lahan kosong 64,488 Ha, Tambak dan rawa 299,690 Ha, Sungai 97,692 Ha, dan Jalan dan parkiran 121,083 Ha. Hasil uji klasifikasi pada interpretasi digital dengan menggunakan metode berbasis objek dan interpretasi manual secara berturut-turut adalah $91,836 \%$, dan $95,918 \%$
\end{abstract}

Kata Kunci : Kesesuaian Lahan, Citra Worldview-2, Klasifikasi Berbasis Objek

\section{PENDAHULUAN}

\section{Latar Belakang}

Wilayah pesisir adalah daerah pertemuan antara darat dan laut, dengan batas ke arah darat meliputi bagian daratan, baik kering maupun terendam air yang masih mendapat pengaruh sifat-sifat laut seperti angin laut, pasangsurut perembesanair laut (infiusi) yang dicirikan oleh vegetasinya yang khas, sedangkan batas wilayah pesisir ke arah laut mencakup bagian atau batas terluar dari daerah paparan benua (continental shelfl), dimana ciri-ciri perairan ini masih di pengaruhi oleh proses alami yang terjadi didarat seperti sedimentasi dan aliran air tawar, maupun proses yang disebabkan oleh kegiatan manusia di darat seperti penggundulan hutan dan pencemaran.
Pemanfaatan lahan di kawasan pesisir menjadi salah satu penyebab utama terjadinya permasalahan pada kawasan pesisir yang mempengaruhi penyimpangan tata guna lahan di suatu kawasan. Untuk mengurangi penyimpangan tata guna lahan dibutuhkan analisis mengenai kesesuaian lahan dengan menggunakan teknologi penginderaan jauh dan SIG (Sistem Informasi Geografis). Kota Surabaya sendiri merupakan ibu kota Propinsi Jawa Timur, Surabaya memiliki potensi pesisir yang sangat potensial untuk dikembangkan. Terdapat perusahaan/industri, permukiman, perikanan tambak, pertanian, dan fasilitas umum yang berkembang dengan cepat di kawasan pesisir Kota Surabaya khususnya pada kecamatan Asemrowo, Krembangan, Pabean Cantikan, dan Semampir.

Dengan demikian perlu dilakukan penelitian di kawasan pesisir Kota Surabaya untuk mengetahui 
pemanfaatan lahan dan kesesuaiannya sehingga dapat memberikan masukan untuk kebijakan lingkungan yang dapat diterapkan di kawasan pesisir Kota Surabaya. Penelitian ini dapat memberikan informasi dan gambaran kondisi lingkungan di wilayah pesisir berdasarkan data kesesuaian lahan menggunakan data penginderaan jauh yaitu Citra Worldview-2 tahun 2013 di wilayah Kota Surabaya yang nantinya di lakukan fungsi analisis SIG dengan menggunakan metode overlay dan buffering (meliputi kesesuaian lahan tambak, konservasi, dan permukiman) untuk memberikan informasi kesesuaian lahan di wilayah pesisir.

\section{Perumusan Masalah}

Dari latar belakang diatas, dapat diperoleh perumusan masalahnya adalah "Bagaimana mengevaluasi kesesuaian tutupan lahan tambak, konservasi, dan permukiman kawasan pesisir utara kota surabaya dengan citra beresolusi tinggi?".

\section{Tujuan Penelitian}

Adapun tujuan dari penelitian ini adalah:

1. Memetakan tutupan lahan wilayah kawasan pesisir utara Kota Surabaya tahun 2013.

2. Memetakan kesesuaian tutupan lahan tambak, konservasi, dan permukiman di kawasan pesisir utara Kota Surabaya

\section{METODOLOGI PENELITIAN}

\section{Lokasi Penelitian}

Lokasi kegiatan penelitian ini bertempat di empat kecamatan yaitu Kecamatan Asemrowo, Kecamatan Krembanagan, Kecamatan Pabean Cantikan, dan Semampir, Kota Surabaya, Propinsi Jawa Timur yang memiliki posisi geografis $7^{\circ} 11^{\prime} 50^{\prime \prime}$ - $7^{\circ} 13^{\prime} 20^{\prime \prime}$ LS dan $112^{\circ} 44^{\prime} 100^{\prime \prime}$ $112^{\circ} 32^{\prime} 40^{\prime \prime}$ BT

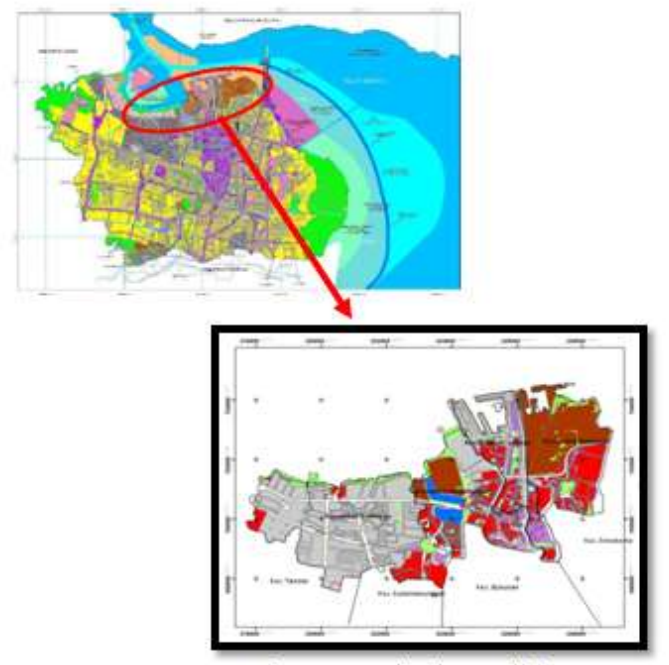

Gambar 1. Lokasi Penelitian

\section{Data Dan Peralatan}

\section{- Data}

Data yang digunakan dalam penelitian tugas akhir ini adalah:

1. Citra satelit yang digunakan adalah citra satelit Worldview 2013 dengan resolusi mencapai 5 meter dan dipadu dengan pengamatan lapangan.Peta gari skala 1:1000 kota Surabaya tahun 2012 dari Dinas Cipta Karya.

2. Data dokumen RDTRK UP V Tanjung Perak dan UP XI Tambak Osowilangon kota Surabaya tahun 2008, dari Badan Perencanaan Pembangunan Kota Surabaya (BAPPEKO).

3. Data lereng, jenis tanah, dan penggunaan lahan di wilayah Kota Surabaya, dari Badan Perencanaan Pembangunan Kota Surabaya (BAPPEKO).

\section{- Peralatan}

Peralatan yang digunakan dalam penelitian ini meliputi :

1. Laptop, digunakan untuk proses pengolahan data, pemodelan hasil, dan penulisan laporan.

2. Hard disk $500 \mathrm{~GB}$, digunakan sebagai media penyimpanan data.

3. GPS handheld, alat untuk pengecekan data di lapangan 


\section{Tahapan Penelitian}

Tahapan yang dilaksanakan dalam pengolahan data ini sebagai berikut :

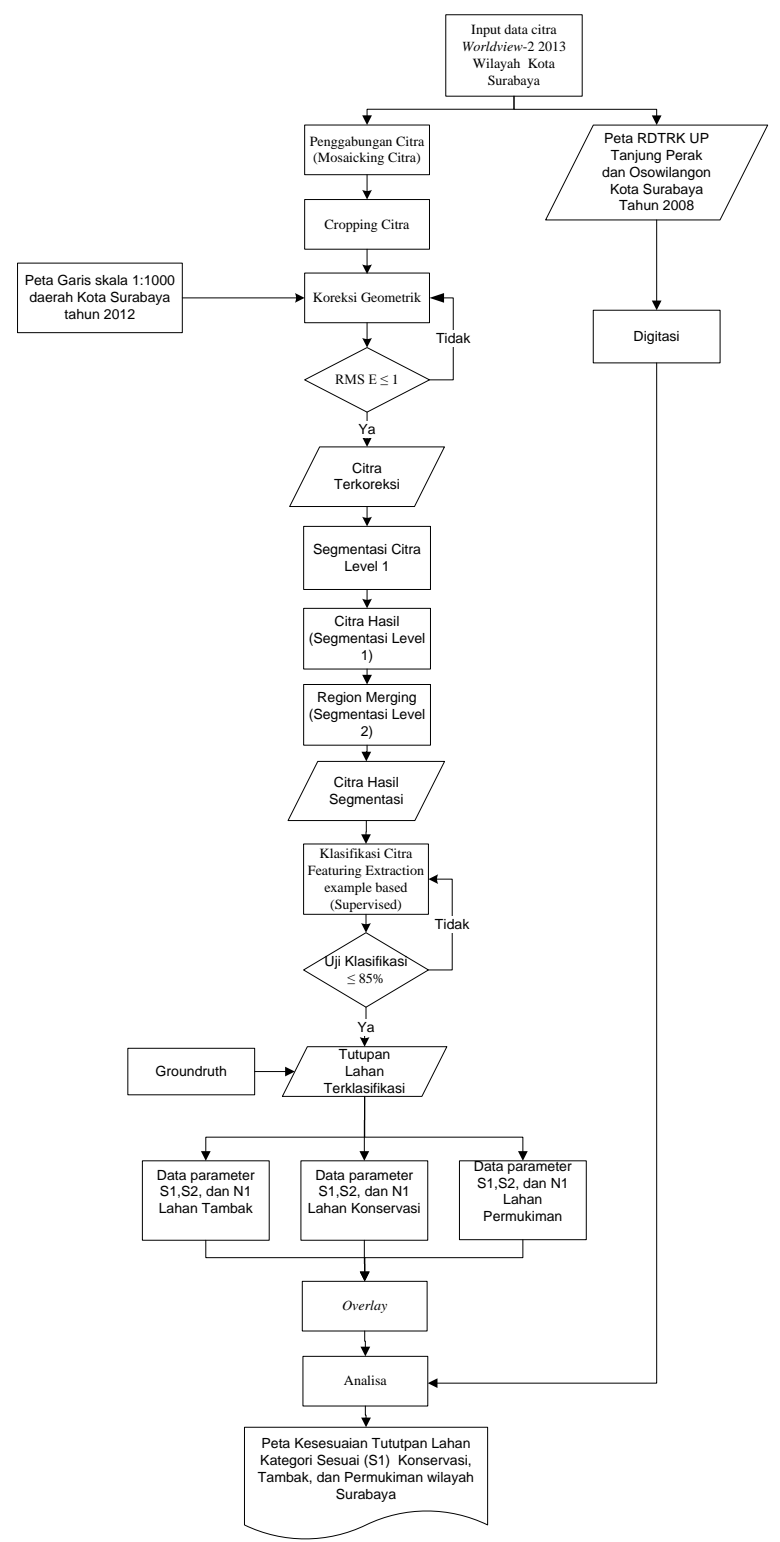

Gambar 2. Diagram Alir Tahapan Pengolahan Data.

Berikut adalah penjelasan diagram alir tahapan pengolahan data spasial:

1. Pemotongan Citra

Proses pemotongan citra adalah untuk memperkecil ukuran citra dan memudahkan pengolahan data. Pemotongan citra dilakukan untuk lebih menfokuskan pengolahan data sesuai dengan daerah penelitian. Pada pemotongan Citra Worldview-2 2013 yang digunakan akan dipotong pada area sekitar pesisir wilayah Kota Surabaya meliputi
Kecamatan Asemrowo, Krembangan, Pabean Cantikan, dan Semampir.

2. Koreksi Geometrik

Dilakukan dengan koordinat yang memerlukan sejumlah titik kontrol di permukaan bumi yang dikenal dengan Ground Control Point (GCP) yang didasarkan pada titik koordinat lintang bujur sudah diketahui. Koreksi Geometrik menggunakan Citra Worldview-2 tahun 2014 dengan peta garis skala 1:1000 tahun 2012 Kota Surabaya. Sistem proyeksi yang dipakai adalah sistem TM 3 (Transverse Mercator), dengan datum WGS (World Geodetic System) 1984.

3. Segmentasi Citra level 1

Pada tahapan ini berfungsi untuk membagi dan memisahkan suatu objek citra menjadi wilayah-wilayah yang homogen berdasarkan kesamaan antara tingkat keabuan suatu pixelpiksel tetangganya. Proses ini terdapat pada proses Feature Extraction Example Based dengan memasukan scale level dan algoritma segementasi untuk menentukan objek apa saja yang akan diekstraksi.

4. Region merging

Proses region merging pada dasarnya adalah memperbaiki kualitas segmentasi dengan melakukan pemisahan segmen berdasarkan spectral dan spasial dengan melakukan penentuan merge level dan algoritma merging yang digunakan.

5. Klasifikasi Berbasis objek

Setelah mendapatkan citra hasil segmentasi dilakukan pemilihan training sample untuk masing kelas yang diinginkan. Semakin banyak menentukan training sample hasil klasifikasi yang di dapatkan akan semakin baik.

\section{Uji Ketelitian}

Setelah nilai piksel area diperoleh dari data citra, maka perlu dievaluasi pola tanggapan spektral setiap kategori tutupan lahan, khususnya kemampuan dalam pemisahan setiap spektralnya. Uji ketelitian klasifikasi yang digunakan dalam penelitian ini yaitu pengambilan sampel dari setiap bentuk 
penutup/penggunaan lahan yang didapatkan dari proses klasifikasi untuk dibandingkan dengan hasil data survey lapangan beberapa titik lokasi.

\section{Analisis}

Setelah mendapatkan data citra yang terklasifikasi akan dianalisis berdasarkan masing-masing parameter disetiap peruntukan yaitu lahan tambak, konservasi, dan permukiman. Pada proses ini dilakukan analisa untuk mendapatkan kesesuaian lahan yang diolah menggunakan Software ArcGIS, dengan mencakup dua tahapan analisis, yaitu dengan menyusunan peta kesesuaian lahan (tambak, konservasi dan permukiman) kawasan pesisir Kota Surabaya dan analisa identifikasi lahan kategori sesuai (S1) dengan peta RDTRK wilayah pesisir Kota Surabaya.

\section{HASIL DAN PEMBAHASAN \\ Koreksi Geometrik}

Pada proses ini bertujuan untuk melakukan transformasi dari suatu sistem grid dengan menggunakan suatu transformasi geometrik sehingga tampilan citra sesuai dengan posisi yang sebenarnya. Untuk koreksi geometrik dilakukan dengan menggunakan Peta digital dengan skala 1 : 1000 Tahun 2012 produk Dinas Cipta Karya dan Tata Ruang Kota Surabaya. Nilai RMSE hasil koreksi geometrik ditunjukan pada tabel 1.

Tabel 1. Perhitungan RMS Error pada Citra Worldview tahun 2012.

\begin{tabular}{|c|c|c|c|c|}
\hline \multicolumn{2}{|c|}{ Koordinat Citra } & \multicolumn{2}{|c|}{ Koordinat Citra } & \multirow{3}{*}{$\begin{array}{l}\text { RMS } \\
\text { Error } \\
\text { (pixel) }\end{array}$} \\
\hline \multicolumn{2}{|c|}{ (Actual) } & \multicolumn{2}{|c|}{ (Predict) } & \\
\hline $\begin{array}{c}X \\
\text { (meter) }\end{array}$ & $\begin{array}{c}Y \\
\text { (meter) }\end{array}$ & $\begin{array}{c}\mathrm{X} \\
\text { (meter) }\end{array}$ & $\begin{array}{c}\mathbf{Y} \\
\text { (meter) }\end{array}$ & \\
\hline 224774.9 & 703922.5 & 224774.9 & 703922.5 & 0.27 \\
\hline 226463.9 & 704253.1 & 226463.2 & 704253.1 & 0.83 \\
\hline 224360.2 & 703699 & 224360.5 & 703699.7 & 0.57 \\
\hline 225889.3 & 702945.3 & 225889.7 & 702945.2 & 0.86 \\
\hline 226987.5 & 703169 & 226986.5 & 703170.5 & 0.73 \\
\hline 224800.6 & 702743.8 & 224800.6 & 702744.7 & 0.79 \\
\hline 224277 & 701814.8 & 224279.6 & 701815.8 & 0.62 \\
\hline 225017.3 & 702039.8 & 225017.3 & 702039.8 & 0.30 \\
\hline 225720.1 & 702081.9 & 225720 & 702082.6 & 0.44 \\
\hline 226246.1 & 701438.8 & 226245.5 & 701439.3 & 0.47 \\
\hline 225570.5 & 701459.4 & 225571.3 & 701459.8 & 0.68 \\
\hline 224323 & 701242.8 & 224324.2 & 701241.9 & 0.93 \\
\hline \multicolumn{4}{|c|}{ Total RMS Error } & 7.49 \\
\hline \multicolumn{4}{|c|}{ Rata-rata RMS Error } & 0.66 \\
\hline
\end{tabular}

Hasil Klasifikasi Citra Dengan Menggunakan Metode Berbasisi Objek

Pada penelitian ini digunakan metode berbasis objek untuk mengklasifikasikan tutupan lahan citra Worldview-2 sebagai kajian lahan permukiman, tambak, dan konservasi di wilayah pesisir kota Surabaya. Hasil klasifikasi yang dibuat pada penelitian ini adalah permukiman, industri dan pergudangan, jalan dan parkiran, RTH (Ruang Terbuka Hijau), tambak dan rawa, lahan kosong, dan sungai. Tutupan lahan tersebut dipilih berdasarkan kebutuhan parameter kesesuaian lahan. Metode klasifikasi berbasis objek ini dibagi menjadi beberapa tahapan yaitu segmentation (segmentasi), region merging, refining (penentuan threshold) dan example based classification.

Adapun parameter scale level yang digunakan pada penelitian ini adalah 20 (segmetation), dan 90 (marge level) serta pada tahapan refine digunakan no threshold karena memberikan hasil segmentasi berupa pendekatan objek citra yang sesungguhnya. Pada penelitian ini parameter segementasi digunakan nilai segmentasi 20 dan nilai merge 90 , karena nilai tersebut memberikan hasil klasifikasi yang mendekati kemiripan objek berdasarkan rona, warna, dan tekstur. Terdapat 2 algoritma pada nilai segmetasi yaitu edge dan intensity. Pada penelitian ini digunakan algoritma edge metode ini lebih baik dalam mendeteksi dan memisahkan fitur objek yang kasar atau tajam. Selain itu terdapat dua algoritma pada penentuan nilai marge yaitu full lambda dan fast lambda, pada penelitian ini digunakan algoritma full lambda, metode ini menggabungkan antara segmen kecil dengan segmen besar, seperti tekstur pohon dan awan yang dimana mengurangi kesalahan pada segmentasi.

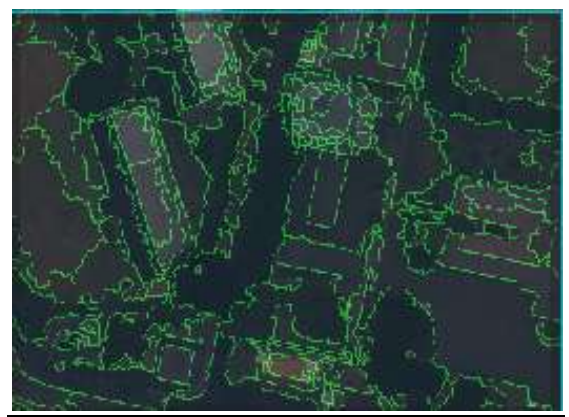

Gambar 2. Nilai Segmentasi; 20, Nilai Merge; 90 Algoritma Segmentasi; Edge, Algoritma Merge; Full Lambda 


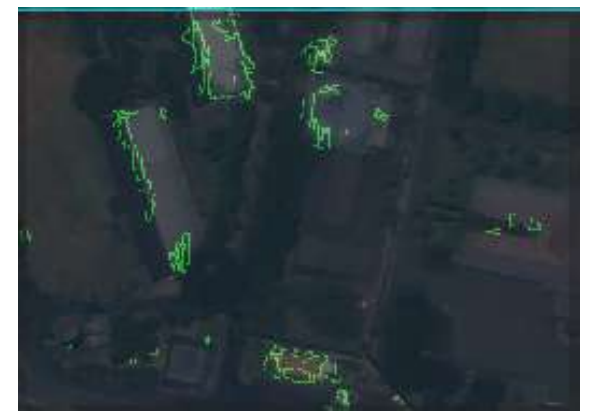

Gambar 3. Nilai Segmentasi; 20, Nilai Merge; 90, Algoritma Segmentasi; Intensity, Algoritma Merge; Fast Lambda

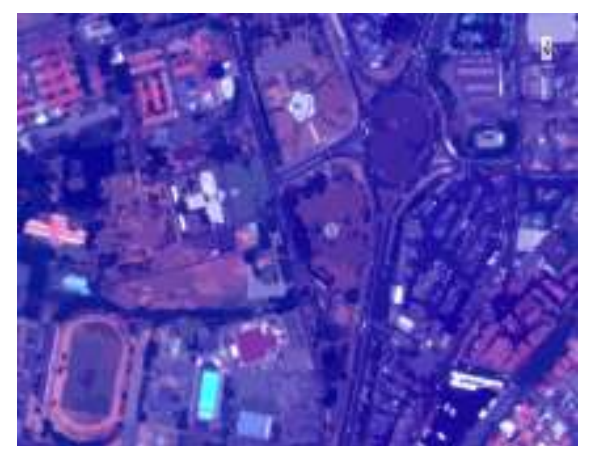

Gambar 4. Hasil segmentasi dan merging citra

Tabel 2. Hasil statistik klasifikasi berbasis objek.

\begin{tabular}{|c|c|c|c|c|c|}
\hline No & $\begin{array}{l}\text { Class } \\
\text { Name }\end{array}$ & $\begin{array}{l}\text { Total } \\
\text { Area } \\
\left(\mathrm{m}^{2}\right) \\
\end{array}$ & $\begin{array}{l}\text { Mean } \\
\text { Area } \\
\left(\mathrm{m}^{2}\right)\end{array}$ & $\begin{array}{l}\text { Min } \\
\text { Area } \\
\left(\mathrm{m}^{2}\right)\end{array}$ & $\begin{array}{l}\text { Max } \\
\text { Area } \\
\left(\mathrm{m}^{2}\right)\end{array}$ \\
\hline & Industri & & & & \\
\hline 1 & $\begin{array}{l}\text { Dan } \\
\text { Pergudang } \\
\text { an }\end{array}$ & $\begin{array}{c}544962 \\
3,6\end{array}$ & 212,485 & 0,494 & $\begin{array}{c}45216 \\
246\end{array}$ \\
\hline 2 & $\begin{array}{l}\text { Jalan Dan } \\
\text { Parkiran }\end{array}$ & $\begin{array}{c}109734 \\
85\end{array}$ & 802,448 & 0,247 & $\begin{array}{c}201410 \\
2,6\end{array}$ \\
\hline 3 & $\begin{array}{l}\text { Lahan } \\
\text { Kosong }\end{array}$ & $\begin{array}{c}705005 \\
0,9\end{array}$ & 321,494 & 0,247 & $\begin{array}{c}64488 \\
594\end{array}$ \\
\hline 4 & $\begin{array}{l}\text { Permukim } \\
\text { an }\end{array}$ & $\begin{array}{c}617453 \\
1,3\end{array}$ & 74,701 & 0,247 & $\begin{array}{c}33803 \\
273\end{array}$ \\
\hline 5 & RTH & $\begin{array}{c}401066 \\
6,5\end{array}$ & 288,807 & 0,247 & $\begin{array}{c}271206 \\
, 53\end{array}$ \\
\hline 6 & $\begin{array}{c}\text { Tambak } \\
\text { dan Rawa }\end{array}$ & $\begin{array}{c}229690 \\
7,4\end{array}$ & 411,558 & 0,247 & $\begin{array}{c}144269 \\
, 94\end{array}$ \\
\hline 7 & Sungai & $\begin{array}{c}432010 \\
66\end{array}$ & $\begin{array}{c}2762,74 \\
6 \\
\end{array}$ & 0,247 & $\begin{array}{c}411688 \\
60\end{array}$ \\
\hline
\end{tabular}

Dari masing-masing kelas pada klasifikasi ini akan dipilih berdasarkan parameter-parameter kesesuaian tutupan lahan yang terdapat pada tabel 3, 4, dan 5. Dari hasil interpretasii digital atau klasifikasi berbasis objek ini terdapat kelemahan dalam memisahkan objek dengan warna yang sama. Maka dibutuhkan interpretasi manual untuk mendapatkan tutupan lahan yang lebih mendekati objek yang sebenarnya.
Pada hasil interpretasi digital yang akan digunakan untuk kesesuaian tutupan lahan yaitu kelas Industri dan pergudangan, jalan dan parkiran, permukiman, RTH (Ruang Terbuka Hijau), tambak dan rawa, dan sungai. Sementara untuk interpretasi manual yang digunakan adalah kelas mangrove, dan hutan pantai. Berikut adalah hasil luasan yang terdapat pada interpretasi manual:

Tabel 3. Hasil Luasan Interpretasi Manual

\begin{tabular}{ccc}
\hline No. & Kelas & $\begin{array}{c}\text { Luas } \\
\mathbf{( H a )}\end{array}$ \\
\hline 1 & Sungai & 97,692 \\
2 & Indutri Dan Pergudangan & 567,333 \\
3 & Tambak Dan Rawa & 287,881 \\
4 & Permukiman & 948,386 \\
5 & Jalan Dan Parkiran & 121,083 \\
6 & RTH & 122,607 \\
7 & Mangrove & 38,141 \\
8 & Hutan Pantai & 28,807 \\
9 & Lahan Kosong & 17,308 \\
\hline
\end{tabular}

Perbandingan Hasil Interpretasi Digital Berbasis Objek dan Interpretasi Manual.

Klasifikasi berbasis objek merupakan hasil klasifikasi secara digital, dan pada proses klasifikasi berbasis objek digunakan proses Example Based Feature Extraction yang digunakan hanya memilih training sample yang telah dipisahkan atau diproses secara digital berdasarkan algoritma dan nilai parameter yang digunakan. Hasil pada klasifikasi berbasis objek hanyalah pendekatan yang merupai objek yang sebenarnya dan terdapat kesalahan.

Berikut adalah hasil peta klasifikasi manual dan klasifikasi berbasis objek.

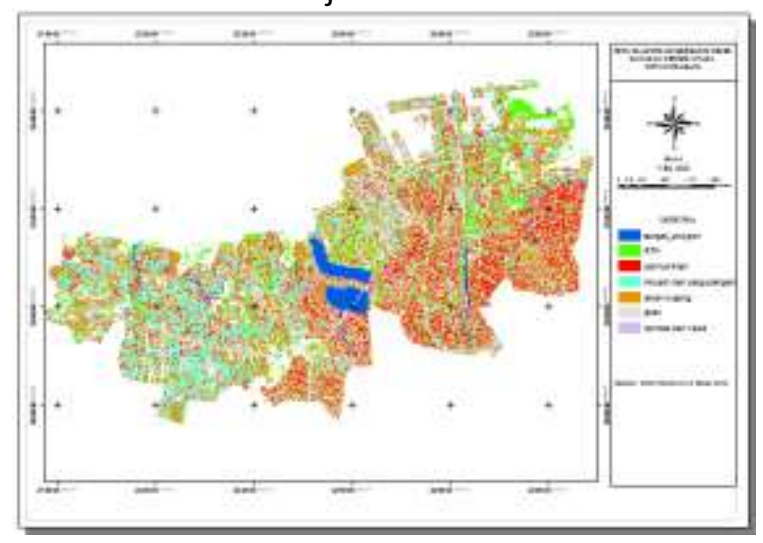

Gambar 5. Hasil Klasifikasi Berbasis Objek 


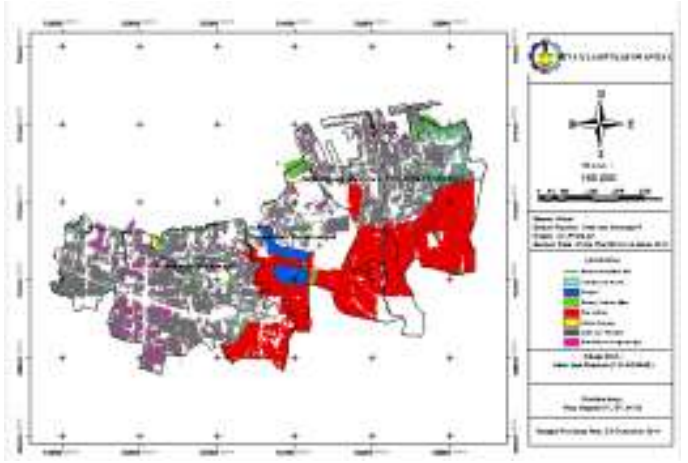

Gambar 6. Hasil Klasifikasi Manual

Berikut ini adalah tingkat ketelitian hasil uji antara hasil uji klasifikasi dengan data lapangan (groundruth) yang berjumlah total 49 titik sampel, berdasarkan 2 jenis Interpretasi yaitu interpretasi manual dan interpretasi digital berbasis objek.

Tabel 4. Ketelitian Interpretasi Manual

\begin{tabular}{|c|c|c|c|c|c|c|c|c|c|}
\hline \multirow{2}{*}{ Kelas } & \multicolumn{7}{|c|}{$\begin{array}{c}\text { Hasil Interpretasi Citra } \\
\text { Worldview-2 }\end{array}$} & \multirow{2}{*}{$\begin{array}{l}\bar{\pi} \\
\stackrel{0}{0}\end{array}$} & \multirow{2}{*}{ 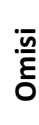 } \\
\hline & 1 & 2 & 3 & 4 & 5 & 6 & 7 & & \\
\hline Perumahan & 8 & & 1 & & & & & 9 & 1 \\
\hline RTH & & 6 & & & & & & 6 & 0 \\
\hline $\begin{array}{l}\text { Industri dan } \\
\text { Pergudangan }\end{array}$ & & & 7 & & & & & 7 & 0 \\
\hline Sungai & & & & 4 & & & & 4 & 0 \\
\hline Lahan Kosong & & & & & 6 & & & 6 & 0 \\
\hline $\begin{array}{l}\text { Jalan dan } \\
\text { Parkiran }\end{array}$ & & & & & & 8 & & 8 & 0 \\
\hline $\begin{array}{l}\text { Tambak dan } \\
\text { Rawa }\end{array}$ & & 1 & & & & & 8 & 9 & 1 \\
\hline Total & 8 & 7 & 8 & 4 & 6 & 8 & 8 & $\begin{array}{l}4 \\
9\end{array}$ & \\
\hline Komisi & 0 & 1 & 1 & 0 & 0 & 0 & 0 & & \\
\hline
\end{tabular}

Tabel 5. Ketelitian Interpretasi Citra Berbasis Objek (Training Sample Digital)

\begin{tabular}{|c|c|c|c|c|c|c|c|c|c|}
\hline \multirow[t]{2}{*}{ Kelas } & \multicolumn{7}{|c|}{$\begin{array}{l}\text { Hasil Interpretasi Citra } \\
\text { Worldview-2 }\end{array}$} & \multirow{2}{*}{ 胥 } & \multirow{2}{*}{ סू } \\
\hline & 1 & 2 & 3 & 4 & 5 & 6 & 7 & & \\
\hline Perumahan & 9 & 0 & 0 & 0 & 0 & 0 & C & 9 & 0 \\
\hline RTH & 0 & 5 & 0 & 0 & 0 & 2 & c & 7 & 2 \\
\hline $\begin{array}{l}\text { Industri dan } \\
\text { Pergudangan }\end{array}$ & 0 & 0 & 7 & 0 & 0 & 0 & 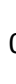 & 7 & 0 \\
\hline Sungai & 0 & 0 & 0 & 4 & 0 & 0 & 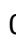 & 4 & 0 \\
\hline Lahan Kosong & 0 & 0 & 0 & 0 & 5 & 0 & 0 & 5 & 0 \\
\hline $\begin{array}{l}\text { Jalan dan } \\
\text { Parkiran }\end{array}$ & 0 & 0 & 0 & 0 & 0 & 6 & 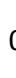 & 6 & 0 \\
\hline $\begin{array}{l}\text { Tambak dan } \\
\text { Rawa }\end{array}$ & 0 & 1 & 0 & 0 & 1 & & s & 11 & 2 \\
\hline Total & 9 & 6 & 7 & 4 & 6 & 8 & s & 49 & \\
\hline Komisi & 0 & 1 & 0 & 0 & 1 & 2 & 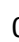 & & \\
\hline
\end{tabular}

Berdasarkan tabel 4 dan 5, digunakan titik data lapangan sebanyak 49 titik, dan dalam uji ketelitian interpretasi ini bertujuan untuk mengetahui nilai kebenaran dari hasil interpretasi manual dan digital dengan data lapangan. Interpretasi manual menunjukan akurasi yang lebih baik dibandingkan interpretasi digital berbasis objek yaitu rata-rata overall accuracy sebesar 95,918\%.

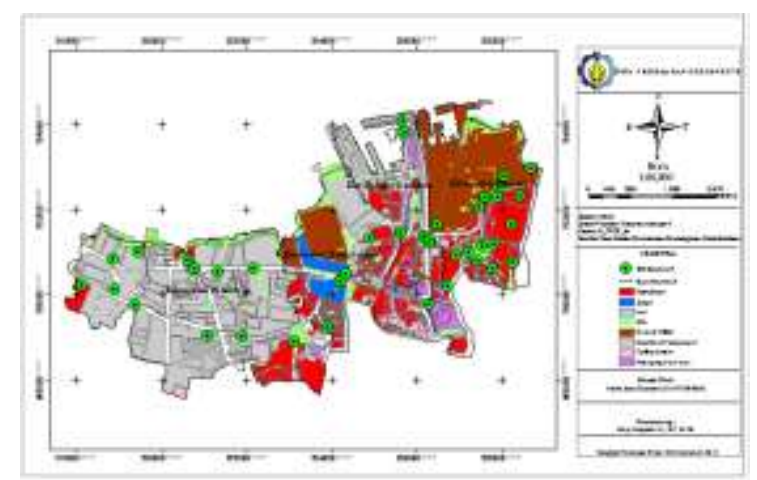

Gambar 7. Persebaran titik Groundruth

Kemudian pada hasil overall accuracy klasifikasi berbasis objek yaitu sebesar 91,836\%. Dengan hasil uji ketepatan interpretasi digital dan manual maka hasil ketepatan dari kedua interpretasi tersebut dianggap benar, karena telah memenuhi toleransi uji klasifikasi yakni $\geq 85 \%$.

\section{Analisa Kesesuaian Tutupan Lahan Pesisir Dengan Hasil Klasifikasi Berbasis Objek Citra Worldview 2013}

Berdasarkan hasil yang didapat luasan daerah lahan tambak kategori sesuai (S1) adalah 862,716 $\mathrm{Ha}$, dan lahan tambak S1 dengan luas tutupan lahan terbesar terdapat di kecamatan Asemrowo sebesar 3,378 Ha. Kemudian luasan lahan tambak kategori sesuai bersyarat (S2) adalah 7812,307, serta kategori tidak sesuai N1 tidak ditemukan.

Tingkat kesesuaian yang didapatkan pada lahan tambak menggunakan parameter-parameter kesesuaian lahan yang digunakan pada penelitian terdahulu. 
Tabel 6. Parameter Tingkat Kesesuaian Lahan Tambak

\begin{tabular}{|c|c|c|c|}
\hline \multirow[b]{2}{*}{ Parameter } & \multicolumn{3}{|c|}{ Tingkat Kesesuaian Lahan Tambak } \\
\hline & Sesuai ( S1) & $\begin{array}{c}\text { Sesuai } \\
\text { Bersyarat } \\
\text { (S2) }\end{array}$ & $\begin{array}{c}\text { Tidak } \\
\text { Sesuai (N1) }\end{array}$ \\
\hline Lereng & $0-8 \%$ (datar) & $\begin{array}{c}\text { 8-15\% } \\
\text { (landai) }\end{array}$ & $\begin{array}{c}<15 \% \\
\text { (curam) }\end{array}$ \\
\hline Tanah & Entisol & Entisol & Non-entisol \\
\hline $\begin{array}{c}\text { Jarak dari } \\
\text { sungai }\end{array}$ & $0-500 \mathrm{~m}$ & $\begin{array}{c}500-2000 \\
\mathrm{~m}\end{array}$ & $>2000 \mathrm{~m}$ \\
\hline $\begin{array}{c}\text { Jarak dari } \\
\text { pantai }\end{array}$ & $0-2000 \mathrm{~m}$ & $\begin{array}{c}2000- \\
4000 \mathrm{~m}\end{array}$ & $>4000 \mathrm{~m}$ \\
\hline $\begin{array}{c}\text { Penggunaa } \\
\text { n lahan }\end{array}$ & $\begin{array}{c}\text { Hutan rawa, } \\
\text { tegalan, } \\
\text { belukar }\end{array}$ & $\begin{array}{l}\text { Sawah, } \\
\text { perkebun } \\
\text { an }\end{array}$ & $\begin{array}{c}\text { Konservasi, } \\
\text { Permukiman, } \\
\text { Industri }\end{array}$ \\
\hline
\end{tabular}

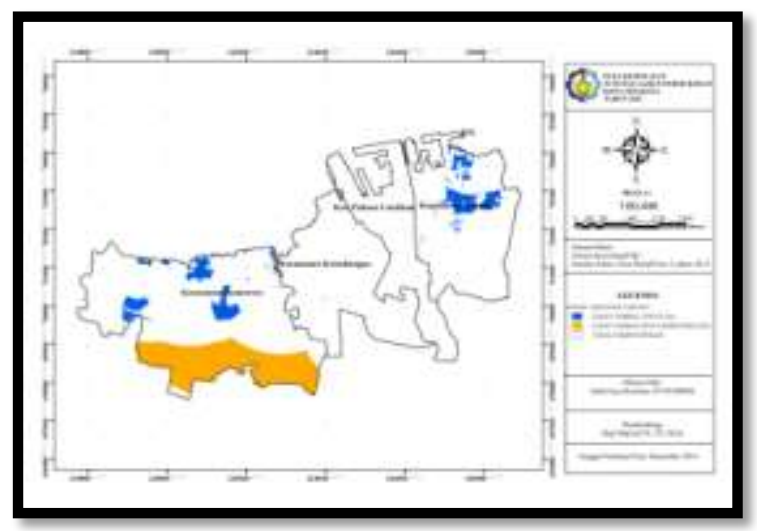

Gambar 8. Hasil Peta Kesesuaian Lahan Tambak

Berdasarkan hasil diatas luasan daerah konservasi kategori sesuai (S1) adalah 34,790 $\mathrm{Ha}$, dan lahan konservasi S1 dengan luas terbesar terdapat di kecamatan Asemrowo sebesar 21,753 Ha. Kemudian luasan lahan konservasi kategori S2 adalah 2,6568 $\mathrm{Ha}$, serta kategori N1 sebesar $68,075 \mathrm{Ha}$. Berdasarkan tingkat kesesuaian lahan untuk lahan konservasi disajikan pada Tabel 7.

Tabel 7. Parameter Kesesuaian Lahan Konservasi

\begin{tabular}{|c|c|c|c|}
\hline \multirow[b]{2}{*}{ Parameter } & \multicolumn{3}{|c|}{ Tingkat Kesesuaian Lahan Konservasi } \\
\hline & $\begin{array}{l}\text { Sesuai } \\
\text { (S1) }\end{array}$ & $\begin{array}{c}\text { Sesuai } \\
\text { Bersyarat } \\
\text { (S2) }\end{array}$ & $\begin{array}{l}\text { Tidak Sesuai } \\
\text { (N1) }\end{array}$ \\
\hline Tanah & Entiosol & Entiosol & $\begin{array}{c}\text { Non- } \\
\text { Entiosol }\end{array}$ \\
\hline Vegetasi & Mangrove & Pinus & Kelapa \\
\hline $\begin{array}{l}\text { Penggunaan } \\
\text { lahan }\end{array}$ & Cagar alam & $\begin{array}{c}\text { Hutan } \\
\text { pantai, } \\
\text { taman } \\
\text { wisata alam }\end{array}$ & $\begin{array}{l}\text { Permukiman } \\
\text {, Pelabuhan }\end{array}$ \\
\hline
\end{tabular}

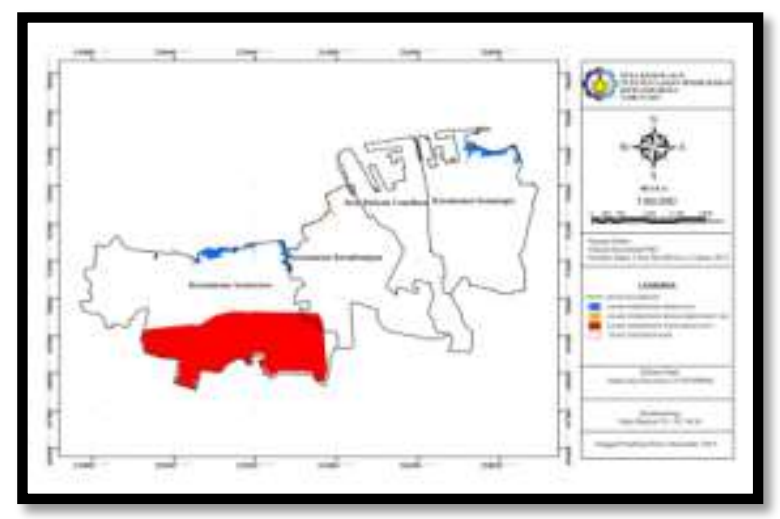

Gambar 9. Hasil Peta Kesesuaian Lahan Konservasi

Berdasarkan hasil yang didapat luasan daerah lahan Permukiman kategori sesuai (S1) adalah 219698,749 $\mathrm{Ha}$, dan kemudian luasan lahan permukiman kategori sesuai bersyarat (S2) adalah 32,341 $\mathrm{Ha}$, dan kategori tidak sesuai N1 adalah 30,925 Ha. Berdasarkan peruntukannya, lahan untuk permukiman dibatasi oleh parameterparameter sebagai berikut:

Tabel 8. Matriks Kesesuaian Lahan Permukiman

\begin{tabular}{|c|c|c|c|}
\hline \multirow[b]{2}{*}{ Parameter } & \multicolumn{3}{|c|}{ Tingkat Kesesuaian Lahan Permukiman } \\
\hline & $\begin{array}{l}\text { Sesuai } \\
\text { ( S1) }\end{array}$ & $\begin{array}{l}\text { Sesuai } \\
\text { Bersyarat } \\
\text { (S2) }\end{array}$ & $\begin{array}{l}\text { Tidak } \\
\text { (N1) }\end{array}$ \\
\hline Lereng & $<8 \%$ (datar) & $\begin{array}{c}8-15 \% \\
\text { (landai) }\end{array}$ & $>15 \%$ (curam) \\
\hline $\begin{array}{c}\text { Jarak dari } \\
\text { rawa }\end{array}$ & $>500 \mathrm{~m}$ & $300-500 \mathrm{~m}$ & $0-299 \mathrm{~m}$ \\
\hline $\begin{array}{c}\text { Jarak dari } \\
\text { daerah } \\
\text { banjir }\end{array}$ & $>200 \mathrm{~m}$ & $300-500 \mathrm{~m}$ & $0-300 \mathrm{~m}$ \\
\hline $\begin{array}{c}\text { Jarak dari } \\
\text { pasang } \\
\text { tertinggi }\end{array}$ & $>300 \mathrm{~m}$ & $150-300 \mathrm{~m}$ & $0-150 \mathrm{~m}$ \\
\hline
\end{tabular}

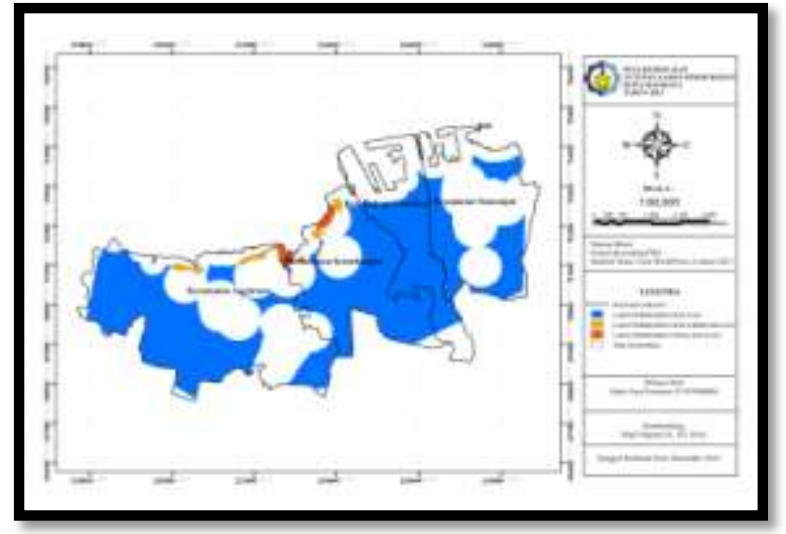

Gambar 10. Hasil Peta Kesesuaian Lahan Permukiman 


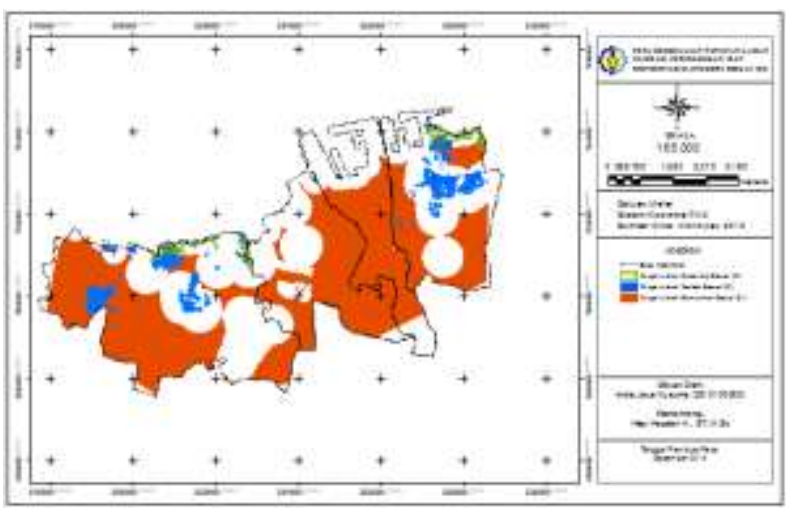

Gambar 11. Hasil Kesesuaian Lahan Sesuai (S1) lahan Tambak, Konservasi dan Permukiman

\section{PENUTUP}

\section{Kesimpulan}

Berdasarkan hasil penelitian kesesuaian tutupan lahan kawasan pesisir kota Surabaya meliputi kecamatan Asemrowo, Krembangan, Pabean Cantikan, dan Semampir, dapat ditarik kesimpulan sebaga berikut:

1. Hasil uji klasifikasi pada interpretasi digital dengan menggunakan metode berbasis objek dan interpretasi manual secara berturut-turut adalah 91,836\%, dan 95,918\%.

2. Hasil tutupan lahan dengan menggunakan klasifikasi berbasisis objek didapatkan 7 kelas yaitu Permukiman 617,453 $\mathrm{Ha}$, Industri dan pergudangan 544,962 $\mathrm{Ha}$, RTH 401,066 $\mathrm{Ha}$, Lahan kosong, Tambak dan rawa 299,690 Ha, Sungai 97,692 $\mathrm{Ha}$, dan Jalan dan parkiran 121,083 Ha.

3. Hasil analisis keesuaian tutupan lahan bagi lahan tambak, konservasi, dan permukiman adalah:

a. Kategori Sesuai (S1) bagi lahan tambak memiliki luas total $862,716 \mathrm{Ha}$.

b. Kategori Sesuai (S1) pada lahan konservasi $34,790 \mathrm{Ha}$.

4. Kategori Sesuai (S1) pada lahan permukiman memiliki luas total 219698,749 Ha

\section{DAFTAR PUSTAKA}

Bengen, Dietriech G, 2002. Pedoman Teknis Pengenalan dan Pengelolaan Ekosistem Mangrove. Bogor. Pusat Kajian Sumberdaya Pesisir dan Lautan IPB.

Khrisna Protecta Adiprima dan Arief Sudradjat. 2012. "Kajian Kesesuaian Lahan Tambak, Konservasi Dan Permukiman
Kawasan Pesisir Menggunakan Sistem Informasi Geografis". Pangandaran, Jawa Barat. Fakultas Teknik Sipil dan Lingkungan, Institut Teknologi Bandung.

Yuniarto Dwi S. 2010. "Kesesuaian Penggunaan Lahan Berdasarkan Tingkat Kerawanan Longsor". Kabupaten Semarang. Program Pascasarjana Universitas Dipenogoro Semarang 